\title{
EFFECT OF PROPOLIS EXTRACT AND PROPOLIS CANDIES ON THE GROWTH OF STREPTOCOCCUS SANGUINIS ATCC 10556
}

\author{
ROZANNA ROZANNA, NURTAMI SOEDARSONO, RATNA FARIDA*
}

Department of Oral Biology, Faculty of Dentistry, Universitas Indonesia, Jakarta, Indonesia. Email: friedakuayu@yahoo.co.id

Received: 20 April 2017, Revised and Accepted: 13 July 2017

ABSTRACT

Objectives: This study aimed to analyze the effects of propolis extract and propolis candies on Streptococcus sanguinis.

Methods: Bacterial suspensions were exposed to propolis extract and propolis candies. For propolis extract, a minimum inhibitory concentration (MIC) was determined using a spectrophotometer, and a minimum bactericidal concentration (MBC) was determined using a standard plate count method. Samples were cultured in brain heart infusion agar, incubated for $24 \mathrm{hrs}$, and the bacterial colony units formed on the agar plates were manually counted.

Results: Propolis extract inhibits the growth of S. sanguinis at MIC 5\% and MBC 10\%. The colonies of S. sanguinis decreased after exposure to propolis candies.

Conclusions: Propolis extract and propolis candies are effective to inhibit the growth of S. sanguinis.

Keywords: Propolis, Streptococcus sanguinis, Caries.

(C) 2017 The Authors. Published by Innovare Academic Sciences PvtLtd. This is an open access article under the CC BY license (http://creativecommons. org/licenses/by/4. 0/) DOI: http://dx.doi.org/10.22159/ajpcr.2017.v10s5.23083

\section{INTRODUCTION}

Dental caries is the most common disease of the oral cavity and the main problem for dental and oral health. In Indonesia, dental caries is highly prevalent. Seventy-five percent of Indonesians experience dental caries with an incidence rate of five teeth per person [1]. One of the Streptococcus bacterial types that exist in oral cavities and causes dental caries is Streptococcus sanguinis. This is an anaerobic facultative bacteria. It is the normal type of bacteria that colonize the oral cavity and can be found in tooth plaque. S. sanguinis bacteria can cause dental caries, endocarditis, periodontal disease, and stomatitis. It is the first bacteria that bonds to the tooth surface and acts as a pioneer in plaque formation, which can then lead to dental caries [2].

As the globalization era develops, perspectives about the approach and maintenance of health have changed. The main focus, now, is to develop more natural innovations in health maintenance practice [3]. The WHO has recommended several natural ingredients as medicines [4]. One of natural ingredients that are presently being researched is propolis. Propolis is a natural remedy and has been used extensively since the early ages. It is now being greatly developed in dentistry [5,6]. Propolis is a resin material collected by Apis mellifera (bees) from plant liquid and plant shoots and then mixed with bees' wax and enzymes. Propolis consists of $45 \%$ resin, $30 \%$ wax and fatty acid, 10\% essential oils, $5 \%$ pollen, and $10 \%$ organic material and minerals [6]. The bioactive ingredient of propolis is a flavonoid that is used in medicine for its biological content. A flavonoid has antibacterial, antifungal, antiviral, antioxidant, and anti-inflammation effects [2]. Propolis is available in the market in various forms of preparations such as capsules, tablets, solutions, cream, and also as an additional ingredient in mouthwash, toothpaste, and candies [7]. Among all the preparation forms, candies are easy to consume, the most practical, and the most acceptable.

Another bee product that also has antibacterial properties is honey. It is collected by bees from flower nectar. Honey contains bioactive ingredients such as phenolics and flavonoids. Just like propolis, honey also has been used extensively in medical fields. Based on the experimental study, honey has proven beneficial for curing wounds, purging infection, and reducing inflammation and pain [8]. Currently, Universitas Indonesia is developing propolis candies. The content of propolis and honey in this candy is expected to prevent the occurrence of oral cavity diseases, especially dental caries. A study about the effect of propolis candies, by Universitas Indonesia, on Streptococcus mutans showed a decline in the prevalence of $S$. mutans. In the present study, the effect of propolis and candies that contain propolis toward $S$. sanguinis was analyzed.

\section{METHODS}

This study was an in vitro laboratory experiment. The sample used in this study was a S. sanguinis ATCC 10556 bacteria strain obtained from the Oral Biology Laboratory, Faculty of Dentistry Universitas Indonesia. Antibacterial tests of propolis extract and propolis candies with sucrose sweetener, propolis candies with palm sugar, and propolis candies X toward S. sanguinis were performed. The efficacy test of propolis extract and propolis candies was undertaken by calculating the concentration of bacteria using an enzyme-linked immunosorbent assay (ELISA) reader, and the amount of bacterial colony was determined by a standard plate count method in colony-forming unit $(\mathrm{CFU}) / \mathrm{ml}$.

\section{Bacterial standardization}

First, $10 \mu \mathrm{L}$ of $S$. sanguinis ATCC 10556 bacteria stock was obtained, spread on agar, and then incubated for $1 \times 24$ hrs. After incubation, $S$. sanguinis bacteria from the agar was taken by wire loop and cultured in $7 \mathrm{ml}$ of BHI and then reincubated for $1 \times 24 \mathrm{hrs}$. After this, $200 \mu \mathrm{L}$ of cultured bacteria was taken and read by an ELISA reader. The bacterial volume was then calculated using the dilution formula: $\mathrm{V}_{1} \mathrm{C}_{1}=\mathrm{V}_{2} \mathrm{C}_{2}$. The calculated bacterial volume was then taken into the BHI (dilution 1). The dilution was performed four times. Then, $10 \mu \mathrm{L}$ of bacteria was taken, planted in agar, and incubated for $1 \times 24 \mathrm{hrs}$.

Various concentrations of propolis extract production Propolis extract was diluted with a glycerin diluting agent to obtain $0.5 \%, 1 \%, 5 \%, 10 \%, 15 \%$, and $20 \%$ concentrations. Every propolis extract concentration was then filtered using a $22 \mu \mathrm{L}$ filter syringe. 
Preparation of candy solution

All the propolis candies, with sucrose sweetener, propolis candies with palm sugar sweetener, and candies X, were crushed with a mortar and a weighed $3 \mathrm{~g}$ portion prepared. Each portion was then added to a measuring cup with $10 \mathrm{ml}$ of BHI in it. The candy solutions were put into an orbital shaker until all the candy solids were dissolved. It was then filtered with a $0.22 \mu \mathrm{L}$ filter syringe.

\section{Bacteria quantity count}

Measured samples $(200 \mu \mathrm{L})$ of $S$. sanguinis, which had previously been cultured in BHI, were put into a 96-well plate and then read by an ELISA reader. Bacteria volume was then calculated using the dilution formula: $\mathrm{V}_{1} \mathrm{C}_{1}=\mathrm{V}_{2} \mathrm{C}_{2}$. The counted bacteria volume was then added to BHI (dilution 1). The diluted bacteria $(100 \mu \mathrm{L})$ was then put into a $96-$ well plate. Each propolis extract concentration $(100 \mu \mathrm{L})$ was added to a 96-well plate. $100 \mu \mathrm{L}$ of bacteria and $100 \mu \mathrm{L}$ of BHI were also added to a 96-well plate as a negative control. About $100 \mu \mathrm{L}$ of each extract concentration and candy solution were also added to a 96-well plate as a blank. The bacteria was then read by an ELISA reader using a wavelength of $450 \mathrm{~nm}$. The bacteria inside the 96-well plate was incubated for $1 \times 24 \mathrm{hrs}$. After $1 \times 24 \mathrm{hrs}$ incubation, the bacteria was reread with an ELISA reader, again using a $450 \mathrm{~nm}$ wave length. The bacteria that had been exposed to propolis extract and various propolis candy solutions was then rediluted, planted in agar, and reincubated for $1 \times 24 \mathrm{hrs}$. The number of bacterial colonies in the agar was then counted in $\mathrm{CFU} / \mathrm{ml}$.

\section{Data analysis}

Propolis extract data analysis was performed using a simple linear regression statistical test and a one-way analysis of variance (ANOVA). The propolis candies data analysis was performed using only an ANOVA test.

\section{RESULTS}

The efficacy of propolis extract toward $S$. sanguinis growth was analyzed by calculating an inhibiting score for each propolis extract concentration. Inhibition is an antimicrobial agent's ability to inhibit microorganism growth. The inhibiting scores were determined by counting the bacterial biomass after it was exposed to various propolis extracts. The bacterial biomass calculation used an optical density score. The inhibiting percentage was calculated by:

Inhibiting score $=1-\left(\frac{\text { OD sampel-OD blank }}{\text { ODbacteria-OD medium }}\right) \times 100 \%$
The inhibiting percentages for various propolis extract concentrations are shown in Table 1. Based on the results (Table 1), $0.5 \%$ concentration propolis extract had an inhibiting score average of $51.4 \%$ (SD \pm 0.35 ) which when compared with the control, without propolis, had a $\mathrm{p}<0.025$. Propolis extract with $1 \%$ concentration had an average inhibiting score of $60.9 \%$ (SD \pm 1.26 ) and $\mathrm{p}<0.025$. Propolis extract with $5 \%$ concentration had a $96.2 \%(S D \pm 2.42)$ average inhibiting score and $\mathrm{p}<0.025$. Propolis extract with $10 \%$ concentration had a $96.4 \%$ (SD \pm 3.21 ) average inhibiting score and $\mathrm{p}<0.025$. Propolis extract with $15 \%$ concentration had a $61.6 \%$ (SD \pm 1.13 ) average inhibiting score and $\mathrm{p}<0.025$. Propolis extract with $20 \%$ concentration had a $39.5 \%$ (SD \pm 5.4 ) average inhibiting score and $p<0.025$.

The inhibiting percentages of propolis extract indicated that the minimum concentration of propolis extract to achieve an inhibiting score $>90 \%$ was a $5 \%$ concentration. Based on visual analysis, the $5 \%$ concentration was clear on the 96-well plate after $24 \mathrm{hrs}$ incubation. In conclusion, this study showed that the minimum inhibitory concentration (MIC) of propolis extract toward S. sanguinis is $5 \%$. Based on ANOVA statistical analysis, the inhibiting scores of various propolis extract concentrations compared to the control without propolis were $\mathrm{p}<0.025$. Statistical tests of propolis extract inhibiting scores using a simple linear regression test showed that the correlation coefficient value was 0.254 which means the correlation of both study variables was in the weak category. In addition, the calculation tests of $S$. sanguinis colonies, after exposure to various concentrations of propolis extract, using the standard plate count method are shown in Table 2.

As shown in Table 2, standard plate counts of each propolis extract calculation showed that at $0.5 \%$ propolis extract concentration, the amount of bacterial colony was as much as $276 \times 10^{7} \mathrm{CFU} / \mathrm{ml}$. Propolis extract with $1 \%$ concentration showed $95 \times 10^{7} \mathrm{CFU} / \mathrm{ml}$ bacterial colonies. Propolis extract with 5\% concentration showed $20 \times 10^{7} \mathrm{CFU} / \mathrm{ml}$ bacterial colonies. On the other hand, for $10 \%, 15 \%$, and $20 \%$ concentrations, bacterial colonies were not found on the agar. As a conclusion, it is determined that the minimum bactericidal concentration (MBC) of propolis extract toward S. sanguinis was $10 \%$ (Fig. 1).

The statistical test, about propolis extract concentration toward the amount of $S$. sanguinis bacterial colony $(\mathrm{CFU} / \mathrm{ml})$, the correlation coefficient was as much as 0.701 . This showed that the correlation between both study variables was in a strong category.

Table 1: Inhibiting scores of various propolis extract concentrations toward S. sanguinis bacterial growth

\begin{tabular}{|c|c|c|c|c|c|}
\hline $\begin{array}{l}\text { Propolis extract } \\
\text { concentration (\%) }\end{array}$ & Sample & $\begin{array}{l}\text { Propolis extract } \\
\text { inhibiting score }(\%)\end{array}$ & $\begin{array}{l}\text { Controlled inhibiting score (without } \\
\text { propolis extract) }(\%)\end{array}$ & $\begin{array}{l}\text { Average of inhibiting } \\
\text { score }(\%) \pm \text { SD }\end{array}$ & $\begin{array}{l}\text { p-value toward } \\
\text { control (without } \\
\text { propolis extract) }\end{array}$ \\
\hline \multirow[t]{3}{*}{0.5} & 1 & 51.7 & 0 & $51.4 \pm 0.35$ & $0.000 *$ \\
\hline & 2 & 51.4 & & & \\
\hline & 3 & 51 & & & \\
\hline \multirow[t]{2}{*}{1} & 1 & 60.7 & 0 & $60.9 \pm 1.26$ & $0.000 *$ \\
\hline & 2 & 58.9 & & & \\
\hline \multirow[t]{3}{*}{5} & 1 & 94.8 & 0 & $96.2 \pm 2.42$ & $0.000 *$ \\
\hline & 2 & 99 & & & \\
\hline & 3 & 94.8 & & & \\
\hline \multirow[t]{3}{*}{10} & 1 & 92.7 & 0 & $96.4 \pm 3.21$ & $0.000^{*}$ \\
\hline & 2 & 97.7 & & & \\
\hline & 3 & 98.7 & & & \\
\hline \multirow[t]{2}{*}{15} & 1 & 60.8 & 0 & $61.6 \pm 1.13$ & $0.000 *$ \\
\hline & 2 & 62.9 & & & \\
\hline \multirow[t]{3}{*}{20} & 1 & 35.5 & 0 & $39.5 \pm 5.4$ & $0.000^{*}$ \\
\hline & 2 & 37.3 & & & \\
\hline & 3 & 45.7 & & & \\
\hline
\end{tabular}

*There was a statistically significant difference ( $\mathrm{p}<0.025)$, S. sanguinis: Streptococcus sanguinis 
The efficacy test of propolis extract was performed by calculating the inhibiting score of each propolis candy toward S. sanguinis growth. Inhibition is an antimicrobial agent's ability to inhibit microorganism growth. An inhibiting score was determined by counting bacterial biomass after it was exposed to various propolis extracts. Bacterial biomass calculation used an optical density score. The inhibiting percentage was calculated with the formula:

Inhibiting score $=1-\left(\frac{\text { OD sampel-OD blank }}{\text { ODbacteria-OD medium }}\right) \times 100 \%$

The inhibiting percentages of various propolis extract concentrations are shown in Table 3. Table 3 shows that propolis candies with sucrose sweetener had a 39.8\% (SD \pm 3.9 ) inhibiting score and the statistical test results revealed a statistically significant difference between sucrosesweetened propolis candy and the non-propolis control with $\mathrm{p}<0.025$. Palm sugar-sweetened propolis candy had a 95.6\% (SD \pm 5.98$)$ inhibiting score, and the statistical test result showed a statistically significant difference between palm sugar-sweetened propolis candy and nonpropolis control with $\mathrm{p}<0.025$. Propolis candy $\mathrm{X}$ had a $25.9 \%$ (SD \pm 2.1 ) inhibiting score, and the statistical test result showed a statistically significant difference between propolis candy $\mathrm{X}$ and the non-propolis control with $p<0.025$. These results revealed that palm sugar-sweetened propolis candy had a higher inhibiting score compared to sucrosesweetened propolis candy and propolis candy X (Fig. 2).

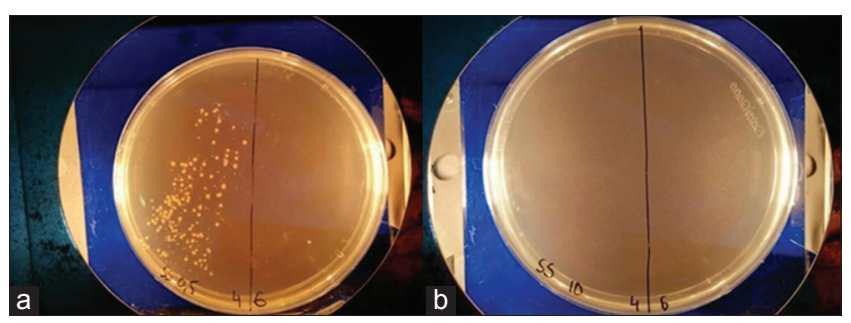

Fig. 1: (a and b) Streptococcus sanguinis colonies after being exposed to propolis extract

Table 2: Amount of S. sanguinis colony after exposure to propolis extract

\begin{tabular}{ll}
\hline $\begin{array}{l}\text { Propolis extract concentration (\%) } \\
\text { and control (without propolis) }\end{array}$ & $\begin{array}{l}\text { Bacterial colony } \\
\text { amount }\left(\mathbf{1 0}^{7} \mathbf{C F U} / \mathbf{m l}\right)\end{array}$ \\
\hline 0.5 & 276 \\
1 & 95 \\
5 & 20 \\
10 & 0 \\
15 & 0 \\
20 & 0 \\
Control without propolis & 1205 \\
\hline
\end{tabular}

S. sanguinis: Streptococcus sanguinis
The count results of S. sanguinis bacterial colonies, which grew on agar after being exposed to propolis candy solution and incubated for $24 \mathrm{hrs}$, are shown in Table 4.

Standard plate count calculations showed that the amount of S. sanguinis bacteria after exposure to various types of propolis candy was lower compared to the control, without propolis candy. The amount of $S$. sanguinis bacterial colony after exposure to palm sugarsweetened propolis candy $(8 \times 109 \mathrm{CFU} / \mathrm{ml})$ was the smallest compared to sucrose-sweetened propolis candy $(41 \times 109 \mathrm{CFU} / \mathrm{ml})$ and propolis candy X $(80 \times 109 \mathrm{CFU} / \mathrm{ml})$.

\section{DISCUSSION}

According to the antibacterial test results of propolis candy toward $S$. sanguinis growth in this study, the colony count result using a standard plate count method showed that palm sugar-sweetened propolis candy, sucrose-sweetened propolis candy, and propolis candy $\mathrm{X}$ were able to decline the growth of $S$. sanguinis compared to a control without propolis candy. This result answered the hypothesis which said that each propolis candy has an antibacterial effect toward S. sanguinis bacteria growth. This study showed that palm sugar-sweetened propolis candies were more effective in reducing $S$. sanguinis growth compared to sucrose-sweetened propolis candies and propolis candies $\mathrm{X}$. This result was based on the calculation of the inhibiting score of each propolis candy. It showed that palm sugar-sweetened propolis candies had a higher inhibiting score compared to sucrose-sweetened propolis candies and propolis candies $\mathrm{X}$.

Based on the calculated amount of colony that grew on agar, the amount of $S$. sanguinis colony that grew on agar after exposure to palm sugar-sweetened propolis candies was lower than sucrose-sweetened propolis candies and propolis candies X. It can be concluded that palm sugar-sweetened propolis candies were the most effective type of propolis candy that can inhibit the growth of $S$. sanguinis if compared to sucrose-sweetened propolis candies and propolis candies X. The result was influenced by the sugar that was used in the propolis candy. Palm sugar is known to have several benefits compared to sucrose such as a lower glycemic index (GI 35) and contains several ingredients that are beneficial for human body such as riboflavin, thiamin, calcium, and other ingredients. Palm sugar also has lower sucrose levels compared to regular granulated sugar. Sucrose is used by bacteria in the fermentation process which can produce energy for bacteria itself.

The previous study reported that sucrose-sweetened propolis candies were able to reduce $S$. mutans prevalence in people who experienced dental caries compared to propolis candies X [9]. However, Safinaz (2014) reported that propolis candies X were more effective compared to sucrose-sweetened propolis candies in reducing myeloperoxidase enzyme activity, an enzyme of saliva that is secreted as a body's defense mechanism toward microorganisms [10]. The sucrose content in propolis candies can help the bacteria production of glucosyltransferase enzymes. These enzymes play a role as a catalyst in glucan formation

Table 3: Inhibiting scores of various propolis candies toward S. sanguinis bacterial growth

\begin{tabular}{|c|c|c|c|c|c|}
\hline Propolis candy type & $\begin{array}{l}\text { Sample } \\
\text { groups }\end{array}$ & $\begin{array}{l}\text { Propolis candy } \\
\text { inhibiting score (\%) }\end{array}$ & $\begin{array}{l}\text { Inhibiting score } \\
\text { control (without propolis } \\
\text { candy) (\%) }\end{array}$ & $\begin{array}{l}\text { Inhibiting score } \\
\text { average }(\%) \pm S D\end{array}$ & $\begin{array}{l}\text { p-values toward } \\
\text { control (without } \\
\text { propolis candy) }\end{array}$ \\
\hline Propolis candy with sucrose & $\begin{array}{l}1 \\
2 \\
3\end{array}$ & $\begin{array}{l}39.9 \\
43.7 \\
35.9\end{array}$ & 0 & $39.8 \pm 3.9$ & $0.001^{*}$ \\
\hline Propolis candy with palm sugar & $\begin{array}{l}1 \\
2 \\
3\end{array}$ & $\begin{array}{l}104.1 \\
81.7 \\
100.9\end{array}$ & 0 & $95.6 \pm 5.89$ & $0.012^{*}$ \\
\hline Propolis candy X & $\begin{array}{l}1 \\
2 \\
3\end{array}$ & $\begin{array}{l}29.1 \\
29.5 \\
19.1\end{array}$ & 0 & $25.9 \pm 12.1$ & $0.000^{*}$ \\
\hline
\end{tabular}

*There was a statistically significant difference $(\mathrm{p}<0.025)$, S. sanguinis: Streptococcus sanguinis 


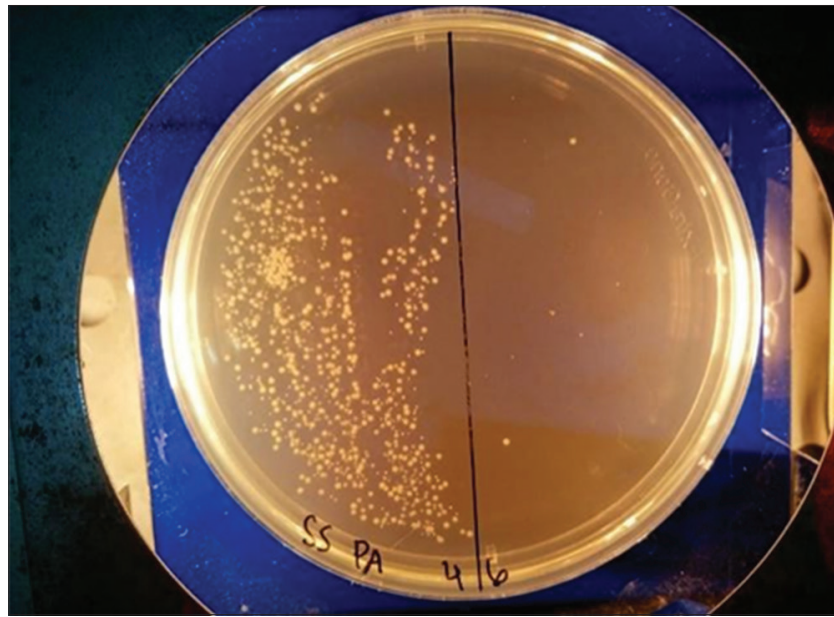

Fig. 2: Streptococcus sanguinis colony after being exposed to propolis candy

Table 4: Amount of $S$. sanguinis colonies after exposure to various types of propolis candy

\begin{tabular}{ll}
\hline $\begin{array}{l}\text { Candy type and control (without } \\
\text { propolis candy) }\end{array}$ & Colony amount $\left(\mathbf{1 0}^{\mathbf{9}} \mathbf{C F U} / \mathbf{m l}\right)$ \\
\hline $\begin{array}{l}\text { Propolis candy with sucrose } \\
\text { sweetener }\end{array}$ & 41 \\
$\begin{array}{l}\text { Propolis candy with palm sugar } \\
\text { sweetener }\end{array}$ & 8 \\
$\begin{array}{l}\text { Propolis candy X } \\
\text { Control (without propolis candy) }\end{array}$ & 830 \\
\hline
\end{tabular}

S. sanguinis: Streptococcus sanguinis

which involves bacteria bonding and colonization [9]. In the current study, colony counting, using a standard plate count method, showed that the higher the concentration of propolis extract the lower the amount of bacterial colony that will be found on the agar compared to a control without propolis. In other words, the higher concentration of propolis extract, the more effective it was to inhibit the growth of $S$. sanguinis bacteria. This result supports the hypothesis: The higher concentration of propolis extract the more effective it will be to reduce $S$. sanguinis growth. These results differed from the calculation obtained using an optical density score. Each propolis extract concentration, calculated using the inhibiting formula, showed that at $0.5-10 \%$ concentration, the increasing inhibitory ability of propolis extract toward $S$. sanguinis occurred. However, at $15-20 \%$ concentration, a declining inhibitory effect of propolis extract toward S. sanguinis occurred.

The different results obtained from the optical density inhibiting score and the colony count using a standard plate count occurred because the optical density score has several weakness and is not suitable as a main method to determine the efficacy of a matter. In conclusion, the standard plate count method was chosen to confirm and control the optical density value. The standard plate count method is known to be more sensitive compared to the spectrophotometry method. This is because the standard plate count only determines viable or living bacteria, so it is more effective to value the efficacy of a matter [11]. Furthermore, optical density value is influenced by various factors such as color and specimen consistency. Propolis extract is dark brown. To obtain the concentration needed for the test, glycerin was used to dilute the propolis extract. This dilution process caused a color change in the propolis extract. The lower the concentration of the extract the lighter the color was and the higher the concentration of the extract, the color was darker. In addition, as the concentration of the propolis increased, the consistency thickened. The color intensity and consistency affected the optical density value. The optical density value can be biased.
The MIC of propolis extract toward S. sanguinis was $5 \%$ because visually, after 24 hrs incubation, $5 \%$ of the concentration had a clear color. The clarity of the sample was used to score bacterial growth. As the sample became darker, the bacterial growth increased. Moreover, the inhibiting score of $5 \%$ propolis extract was $>90 \%$. Oda et al. (2015) studied the MIC and MBC of Brazilian propolis toward S. sanguinis and reported that the MIC of Brazilian propolis toward S. sanguinis was $50 \mu \mathrm{g} / \mathrm{ml}$ or $0.005 \%$ and the MBC was $200 \mu \mathrm{g} / \mathrm{ml}$ or $0.02 \%$ [12]. Elbaz and Elsayad compared the antibacterial effect of Egyptian propolis and New Zealand propolis toward $S$. mutans and reported that New Zealand propolis had a higher antibacterial effect compared to Egyptian propolis [13]. According to Sforcin and Bankova (2011), this result was caused by the varying content of propolis. Content of propolis varies depending on the provenance, the type of plant that propolis was collected from, and the climate [14]

\section{CONCLUSION}

The study, about the effect of propolis extract and propolis candies toward S. sanguinis, showed that propolis extract was effective in inhibiting $S$. sanguinis growth, and various types of propolis candies, such as sucrose-sweetened propolis candies, palm sugarsweetened candies, and propolis candies $\mathrm{X}$, could reduce the amount of $S$. sanguinis colonies. Further study about the efficacy of propolis extract toward $S$. sanguinis using methods other than spectrophotometry is required to avoid the inaccuracy of optical density values as a result of the color influence of each propolis extract concentration.

\section{REFERENCES}

1. Indonesian Ministry of Health. Tidak Sehat Jika Tidak Memiliki Gigi-Mulut Sehat; 2011. Available from: http://www.depkes.go.id/ article/view/1642/tidaksehat-jika-tidak-memiliki-gigi--mulut-sehat. html\#sthash.rSL9rhS7.dpuf.

2. Caufield PW, Dasanayake AP, Li Y, Pan Y, Hsu J, Hardin JM. Natural history of Streptococcus sanguinis in the oral cavity of infants: Evidence for a discrete window of infectivity. Infect Immun 2000;68(7):4018-23.

3. Hegde KS, Bhat SS, Rao A, Sain S. Effect of propolis on Streptococcus mutans counts: An in vivo study. Int J Clin Pediatr Dent 2013;6:22-5.

4. Jon CT, Ted JK. Herbal Medicine Research and Global Health: An Ethical Analysis; 2015. Available from: http://www.who.intbulletin/ volumes/86/8/07-042820/en.

5. Castaldo S, Capasso F. Propolis, an old remedy used in modern medicine. Fitoterapia 2002;73 Suppl 1:S1-6.

6. Tylkowski B, Trusheva B, Bankova V, Giamberini M, Peev G, Nikolova A. Extraction of biologically active compounds from propolis and concentration of extract by nanofiltration. J Memb Sci 2010;348(1-2):124-30.

7. Koru O, Toksoy F, Acikel CH, Tunca YM, Baysallar M, Uskudar Guclu A, et al. In vitro antimicrobial activity of propolis samples from different geographical origins against certain oral pathogens. Anaerobe 2007;13(3-4):140-5

8. Osés SM, Pascual-Maté A, Fernández-Muiño MA, López-Díaz TM, Sancho MT. Bioactive properties of honey with propolis. Food Chem 2016;196:1215-23

9. Buchan RA, Jenkinson HF. Glucosyltransferase production by Streptococcus sanguis Challis and comparison with other oral streptococci. Oral Microbiol Immunol 1990;5(2):63-71.

10. Safinaz D. Pengaruh Konsumsi Permen Propolis Madu Terhadap Aktivitas Enzim Mieloperoksidase Pada Saliva Terstimulasi [Skripsi]. Fakultas Kedokteran Gigi. Depok: Universitas Indonesia; 2014.

11. Reynolds J. Counting Bacteria; 2011. Available from: http://www. delrio.dcced.edu/jreynolds/microbiology/2421/lab_manual/counts.pdf.

12. Oda H, Nakagawa T, Maruyama K, Dono Y, Katsuragi H, Sato S. Effect of Brazilian green propolis on oral pathogens and human periodontal fibroblasts. J Oral Biosci 2015;58(2):50-4.

13. Elbaz GA, Elsayad II. Comparison of the antimicrobial effect of Egyptian propolis vs New Zealand propolis on Streptococcus mutans and lactobacilli in saliva. Oral Health Prev Dent 2012;10(2):155-60.

14. Sforcin JM, Bankova V. Propolis: Is there a potential for the development of new drugs? J Ethnopharmacol 2011;133(2):253-60. 